\title{
Synthesis of Some \\ 5-[2-Aryl-2-oxoethyl]-1,3-dimethylpyrimidine-2,4,6-trione Derivatives by a One-pot, Three-component Reaction
}

\author{
Jabbar Khalafy ${ }^{\mathrm{a}, *}$, Mahnaz Ezzati ${ }^{\mathrm{a}}$, Parinaz Madadi ${ }^{\mathrm{a}}$, \\ Ahmad Poursattar Marjani ${ }^{\mathrm{a}, \star}$ and Hooman Yaghoobnejad Asl ${ }^{\mathrm{b}}$ \\ ${ }^{a}$ Department of Organic Chemistry, Faculty of Chemistry, Urmia University, Urmia, Iran. \\ ${ }^{b}$ Department of Chemistry, Missouri University of Science and Technology, Rolla, MO 65409, USA.
}

Received 29 March 2017, revised 17 July 2017, accepted 17 July 2017.

\begin{abstract}
This study reports the reduction of $\alpha, \beta$-unsaturated ketones $4 \mathrm{a}-\mathrm{g}$, formed by condensation of arylglyoxals $2 \mathrm{a}-\mathrm{g}$ with 1,3-dimethylbarbituric acid (3) by L-cysteine (5) in the presence of phosphotungstic acid as a catalyst. This reaction leads to the formation of 5-[2-aryl-2-oxoethyl]-1,3-dimethylpyrimidine-2,4,6-triones 6a-g, with no sign of any heterocyclic product formation. The structure of compound $6 \mathrm{f}$ was confirmed by X-ray crystallography.
\end{abstract}

KEYWORDS

Arylglyoxals, L-cysteine, 1,3-dimethylbarbituric acid, phosphotungstic acid, one-pot, multi-component reaction.

\section{Introduction}

Multi-component reactions have many advantages over classical reactions, such as low cost and energy consumption, easier isolation and purification, greater atom economy as well as using green solvents with excellent chemo- and regioselectivities. ${ }^{1-6}$

Barbituric acids play an important role in many drugs with biological and pharmaceutical properties. ${ }^{7-16}$ They are wellknown as anticonvulsants, hypnotics, sedatives, and anxiolytic agents. ${ }^{17-22}$ Although barbituric acid itself is hypnotically inactive, its derivatives substituted at C-5 are reported as central nervous system depressants. ${ }^{23}$ The synthesis of 5-[2-aryl-2-oxoethyl]-1,3-dimethylpyrimidine-2,4,6-trione derivatives by reaction of arylglyoxal hydrates and 1,3-dimethylbarbituric acid in the presence of guanidine salts has also been reported under reflux or microwave conditions. ${ }^{24}$

Reduction of 5-arylidene-1,3-dimethylbarbituric acid derivatives with a series of thiols has been reported ${ }^{25}$ (Scheme 1 ). In this study, we have investigated whether the amino acid cysteine would lead merely to reduced products, as shown in Scheme 1, or whether conjugate addition of the thiol group might lead to a new series of potential medicinally active compounds.

Herein, we investigate the one-pot, three-component reaction of 1,3-dimethylbarbituric acid, arylglyoxals and L-cysteine in the presence of phosphotungstic acid as a catalyst in $\mathrm{H}_{2} \mathrm{O} / \mathrm{EtOH}$ under reflux conditions.

\section{Experimental}

\section{General Procedures}

The chemicals used in this work were purchased from Acros Organics or from Merck and were used without purification. Melting points were measured on a Philip Harris C4954718 apparatus. ${ }^{1} \mathrm{H}$ and ${ }^{13} \mathrm{C}-\mathrm{NMR}$ spectra were recorded on a Bruker

* To whom correspondence should be addressed.

E-mail: jkhalafi@yahoo.com / j.khalafi@urmia.ac.ir / a.poursattar@urmia.ac.ir
Avance AQS $300 \mathrm{MHz}$ spectrometer at 300 and $75 \mathrm{MHz}$, respectively. Chemical shifts were measured in $\mathrm{CDCl}_{3}$ as solvent relative to TMS as the internal standard. Infrared spectra were recorded on a Thermo-Nicolet Nexus 670 FT-IR instrument using $\mathrm{KBr}$ discs. Elemental analyses were performed using a Leco Analyzer 932. Mass spectra were recorded on an Agilent Technologies (HP) MS Model: 5975C VL MSD mass spectrometer operating at EI $70 \mathrm{eV}$.

Sample procedure for the synthesis of 5-(2-aryl-2-oxoethyl)1,3-dimethylpyrimidine-2,4,6(1H,3H,5H)-trione (6a-g)

A mixture of 1,3-dimethylbarbituric acid (3) $(1 \mathrm{mmol})$ and arylglyoxals $2(1 \mathrm{mmol})$ in water $(3 \mathrm{~mL})$ was stirred at room temperature for the period of time indicated in Table 1. After compeletion of intermediate formation (tlc, using $\mathrm{MeOH}$ : Hexane: $\mathrm{CHCl}_{3} / 1: 3: 15$ as eluents, $\left.R_{\mathrm{f}}=0.57-0.62\right)$, L-cysteine $(2 \mathrm{mmol})$, phosphotungstic acid $(10 \% \mathrm{~mol})$ and ethanol $(1.5 \mathrm{~mL})$ were added to the reaction mixture, which was refluxed for 1-2 h, during which time the L-cystine was precipitated. The precipitate was filtered and the filtrate was extracted with chloroform. The organic layer was separated, washed with water and dried over $\mathrm{Na}_{2} \mathrm{SO}_{4}$. Removal of solvent gave the desired products as colourless crystals in 69-77\% yields.

1,3-Dimethyl-5-(2-oxo-2-phenylethyl)pyrimidine-2,4,6(1H,3H, $5 H$ )-trione (6a): $R_{\mathrm{f}}=0.57$. Colourless crystals; $71 \%$; m.p. $190{ }^{\circ} \mathrm{C}$ [lit. $\left.{ }^{24} 190-191{ }^{\circ} \mathrm{C}\right] ; \delta_{\mathrm{H}}: 7.96(2 \mathrm{H}, \mathrm{d}, J=8.1 \mathrm{~Hz}, \mathrm{Ar}), 7.69(1 \mathrm{H}, \mathrm{d}, J=$ $6.6 \mathrm{~Hz}, \mathrm{Ar}), 7.49(2 \mathrm{H}, \mathrm{t}, J=8.1 \mathrm{~Hz}, \mathrm{Ar}), 4.05\left(2 \mathrm{H}, \mathrm{d}, J=3.3 \mathrm{~Hz}, \mathrm{CH}_{2}\right)$, $3.61(1 \mathrm{H}, \mathrm{t}, J=3.3 \mathrm{~Hz}, \mathrm{CH}), 3.37(6 \mathrm{H}, \mathrm{s}, 2 \times \mathrm{NMe}) \mathrm{ppm} ; \delta_{\mathrm{c}}: 196.9$, 168.0, 151.7, 135.3, 134.0, 129.8, 128.8, 44.5, 37.8, 28.8 ppm; FT-IR $v_{\max }: 3427,2892,1667,1463,139,1306,1218,1113,1031,764$, $691 \mathrm{~cm}^{-1} \cdot \mathrm{m} / z: 274[\mathrm{M}]^{+}(24), 169(5), 105\left[\mathrm{C}_{6} \mathrm{H}_{5} \mathrm{CO}\right]^{+}(100), 77(48)$, 55 (9), 51 (8).

5-(2-(4-Chlorophenyl)-2-oxoethyl)-1,3-dimethylpyrimidine-2, 4,6(1H,3H,5H)-trione (6b): $R_{\mathrm{f}}=0.59$. Colourless crystals; $75 \%$; m.p. $166^{\circ} \mathrm{C} ; \delta_{\mathrm{H}}: 7.88(2 \mathrm{H}, \mathrm{d}, J=8.4 \mathrm{~Hz}, \mathrm{Ar}), 7.45(2 \mathrm{H}, \mathrm{d}, J=8.4 \mathrm{~Hz}$, 
<smiles>[R]c1cc([N+](=O)[O-])ccc1C=C1C(=O)N(C)C(=O)N(C)C1=O</smiles>

$$
\mathrm{R}=\mathrm{H}, \mathrm{NO}_{2}
$$<smiles>[R]S[SH][R]</smiles>

Scheme 1

Reduction of 5-arylidene-1,3-dimethylbarbituric acid derivatives with thiols.
Ar), $3.98\left(2 \mathrm{H}, \mathrm{d}, J=3.9 \mathrm{~Hz}, \mathrm{CH}_{2}\right), 3.61(1 \mathrm{H}, \mathrm{t}, J=3.9 \mathrm{~Hz}, \mathrm{CH}), 3.35$ $(6 \mathrm{H}, \mathrm{s}, 2 \times \mathrm{NMe}) \mathrm{ppm} ; \delta_{\mathrm{c}}: 195.8,167.8,151.6,140.5,133.6,129.7$, 129.1, 44.5, 37.6, 28.8 ppm; FT-IR $v_{\text {max }}$ : 3424, 2883, 1667, 1589, 1463, 1377, 1219, 1097, 1034, 819, $755 \mathrm{~cm}^{-1}$; Found: C, 54.52; H, 4.11; N, $9.16 \%$. Calc. for $\mathrm{C}_{14} \mathrm{H}_{13} \mathrm{ClN}_{2} \mathrm{O}_{4}$ (308.72); C, 54.47; $\mathrm{H}, 4.24 ; \mathrm{N}$, $9.07 \% . m / z: 310[\mathrm{M}+2]^{+}(20), 308[\mathrm{M}]^{+}(54), 169(22), 141$ $\left[4{ }^{37} \mathrm{ClC}_{6} \mathrm{H}_{4} \mathrm{CO}\right]^{+}(100), 140(42), 139\left[4-{ }^{35} \mathrm{ClC}_{6} \mathrm{H}_{4} \mathrm{CO}\right]^{+}(100), 113$ (35), 111 (87), 75 (31), 55 (22).

5-(2-(4-Fluorophenyl)-2-oxoethyl)-1,3-dimethylpyrimidine-2,4, $\mathbf{6}(\mathbf{1 H}, \mathbf{3 H}, \mathbf{5 H})$-trione $(\mathbf{6 c}): R_{\mathrm{f}}=0.62$. Colourless crystals; $69 \%$; m.p. $162{ }^{\circ} \mathrm{C}\left[\right.$ lit. $\left.{ }^{24} 162-163{ }^{\circ} \mathrm{C}\right] ; \delta_{\mathrm{H}}: 7.98(2 \mathrm{H}, \mathrm{t}, J=8.4 \mathrm{~Hz}, \mathrm{Ar}), 7.16$ $(2 \mathrm{H}, \mathrm{t}, J=8.4 \mathrm{~Hz}, \mathrm{Ar}), 4.02\left(2 \mathrm{H}, \mathrm{d}, J=3.6 \mathrm{~Hz}, \mathrm{CH}_{2}\right), 3.60(1 \mathrm{H}, \mathrm{t}, J=$ $3.6 \mathrm{~Hz}, \mathrm{CH}), 3.37(6 \mathrm{H}, \mathrm{s}, 2 \times \mathrm{NMe}) \mathrm{ppm} ; \delta_{\mathrm{C}}: 195.3,167.9,164.5$, 151.7, 131.8, 131.8, 131.1, 131.0, 116.1, 115.8, 44.5, 37.7, 28.8 ppm. FT-IR $v_{\text {max }}: 3389,3335,3062,2930,2885,1665,1606,1464,1379$, $1312,1229,1151,1111,1033,833,751,562 \mathrm{~cm}^{-1}$.

1,3-Dimethyl-5-(2-oxo-2-( $p$-tolyl)ethyl)pyrimidine-2,4,6(1H, $3 \mathrm{H}, 5 \mathrm{H})$-trione $(\mathbf{6 d}): R_{\mathrm{f}}=0.58$. Colourless crystals; $76 \%$; m.p. $174{ }^{\circ} \mathrm{C} ; \delta_{\mathrm{H}}: 7.84(2 \mathrm{H}, \mathrm{d}, J=7.8 \mathrm{~Hz}, \mathrm{Ar}), 7.27(2 \mathrm{H}, \mathrm{d}, J=6.6 \mathrm{~Hz}, \mathrm{Ar})$, $4.02\left(2 \mathrm{H}, \mathrm{d}, J=3.3 \mathrm{~Hz}, \mathrm{CH}_{2}\right), 3.57(1 \mathrm{H}, \mathrm{t}, J=3.3 \mathrm{~Hz}, \mathrm{CH}), 3.36(6 \mathrm{H}$, s, $2 \times \mathrm{NMe}), 2.42\left(3 \mathrm{H}, \mathrm{s}, \mathrm{CH}_{3}\right) \mathrm{ppm} ; \delta_{\mathrm{c}}: 195.5,168.0,151.7,144.9$, $130.4,129.5,128.4,43.7,36.1,29.7,27.9,26.5$ ppm; FT-IR $v_{\max }$ : 3429, 2945, 2876, 1669, 1464, 1383, 1233, 1109, 1037, 815, 757, 573, $500 \mathrm{~cm}^{-1}$; Found: C, 62.33; H, 5.68; N, $9.60 \%$. Calc. for $\mathrm{C}_{15} \mathrm{H}_{16} \mathrm{~N}_{2} \mathrm{O}_{4}$ (288.30); C, 62.49; H, 5.59; N, 9.72\% . m/z: $288\left(\mathrm{M}^{+}, 88\right), 169$ (13), 120 (99), 119 [4- $\left.\mathrm{MeC}_{6} \mathrm{H}_{4} \mathrm{CO}\right]^{+}$(100), 92 (22), 91 (98), 90 (22), 89 (26), 65 (76), 66 (15), 58 (15), 56 (21), 55 (42).

5-(2-(4-Methoxyphenyl)-2-oxoethyl)-1,3-dimethylpyrimidine2,4,6(1H,3H,5H)-trione (6e): $R_{\mathrm{f}}=0.58$. Colourless crystals; $69 \%$; m.p. $197^{\circ} \mathrm{C} ; \delta_{\mathrm{H}}: 7.93(2 \mathrm{H}, \mathrm{d}, J=9 \mathrm{~Hz}, \mathrm{Ar}), 6.95(2 \mathrm{H}, \mathrm{d}, J=9 \mathrm{~Hz}, \mathrm{Ar})$, $4.01\left(2 \mathrm{H}, \mathrm{d}, J=3.9 \mathrm{~Hz}, \mathrm{CH}_{2}\right), 3.89\left(3 \mathrm{H}, \mathrm{s}, \mathrm{CH}_{3}\right), 3.56(1 \mathrm{H}, \mathrm{t}, J=3.3$ $\mathrm{Hz}, \mathrm{CH}), 3.37$ (6H, s, $2 \times \mathrm{NMe})$ ppm; $\delta_{\mathrm{C}}: 195.2,168.1,164.1,151.7$, $130.6,128.4,113.9,55.5,44.5,37.6,29.7,28.7$ ppm; FT-IR $v_{\max }: 3391$, 3319, 2942, 2891, 1664, 1604, 1375, 1250, 1167, 1111, 1027, 827, 749, $563 \mathrm{~cm}^{-1}$; Found: C, 59.10; $\mathrm{H}, 5.42 ; \mathrm{N}, 9.17 \%$. Calc. for $\mathrm{C}_{15} \mathrm{H}_{16} \mathrm{~N}_{2} \mathrm{O}_{5}$ (304.30); C, 59.21; H, 5.30; N, $9.21 \%$. m/z: $304[\mathrm{M}]^{+}$(20), 136 (16), 135 [4-MeOC $\left._{6} \mathrm{H}_{4} \mathrm{CO}\right]^{+}$(100), 107 (10), 92 (18), 77 (24), 55 (11).

5-(2-(3,4-Dimethoxyphenyl)-2-oxoethyl)-1,3-dimethylpyrimidine-2,4,6(1H,3H,5H)-trione (6f): $R_{\mathrm{f}}=0.60$. Colourless crystals; $77 \%$; m.p. $181^{\circ} \mathrm{C} ; \delta_{\mathrm{H}}: 7.62(1 \mathrm{H}, \mathrm{d}, J=8.7 \mathrm{~Hz}, \mathrm{Ar}), 7.43(1 \mathrm{H}, \mathrm{s}, \mathrm{Ar})$, $6.90(1 \mathrm{H}, \mathrm{d}, J=8.4 \mathrm{~Hz}, \mathrm{Ar}), 4.01\left(2 \mathrm{H}, \mathrm{d}, J=3.6 \mathrm{~Hz}, \mathrm{CH}_{2}\right), 3.95(3 \mathrm{H}$, $\mathrm{s}, \mathrm{OMe}), 3.90(3 \mathrm{H}, \mathrm{s}, \mathrm{OMe}), 3.56(1 \mathrm{H}, \mathrm{t}, J=3.6 \mathrm{~Hz}, \mathrm{CH}), 3.36(6 \mathrm{H}, \mathrm{s}$, $2 \times \mathrm{NMe})$ ppm; $\delta_{\mathrm{c}}: 195.5,168.2,154.1,151.7,149.1,128.5,124.5$, $111.1,58.8,56.8,55.2,43.8,37.5,29.7,27.8$ ppm; FT-IR $v_{\max }: 2949$, 2862, 1673, 1587, 1442, 1378, 1264, 1153, 1020, $753 \mathrm{~cm}^{-1}$; Found: C, 57.56; H, 5.30; N, 8.25\%. Calc. for $\mathrm{C}_{16} \mathrm{H}_{18} \mathrm{~N}_{2} \mathrm{O}_{6}(334.43) ; \mathrm{C}, 57.48 ; \mathrm{H}$, 5.43; N, $8.38 \% . m / z: 335[\mathrm{M}+1]^{+}(16), 334[\mathrm{M}]^{+}(74), 166(34), 165$ $\left[3,4-(\mathrm{MeO})_{2} \mathrm{C}_{6} \mathrm{H}_{3} \mathrm{CO}\right]^{+}(100), 137$ (21), 122 (12), 107 (11), 79 (19), 77 (18), 55 (18)

5-(2-(4-Hydroxy-3-methoxyphenyl)-2-oxoethyl)-1,3-dimethylpyrimidine-2,4,6(1H,3H,5H)-trione $(\mathbf{6 g}): R_{\mathrm{f}}=0.61$. Colourless crystals; $72 \%$; m.p. $199^{\circ} \mathrm{C} ; \delta_{\mathrm{H}}: 7.60-7.57(1 \mathrm{H}, \mathrm{m}, \mathrm{Ar}), 7.44(1 \mathrm{H}, \mathrm{d}, J$ $=0.3 \mathrm{~Hz}, \mathrm{Ar}), 6.97(1 \mathrm{H}, \mathrm{d}, J=8.1 \mathrm{~Hz}, \mathrm{Ar}), 6.15(1 \mathrm{H}, \mathrm{s}, \mathrm{Ar}), 4.02(2 \mathrm{H}$, $\left.\mathrm{d}, J=3.6 \mathrm{~Hz}, \mathrm{CH}_{2}\right), 3.92\left(3 \mathrm{H}, \mathrm{s}, \mathrm{CH}_{3}\right), 3.56(1 \mathrm{H}, \mathrm{t}, J=3.6 \mathrm{~Hz}, \mathrm{CH})$, $3.37(6 \mathrm{H}, \mathrm{s}, 2 \times \mathrm{NMe})$ ppm; $\delta_{\mathrm{c}}: 195.4,168.1,151.2,146.7,124.0$, 114.0, 109.8, 56.0, 44.6, 37.5, 28.8 ppm; FT-IR $v_{\max }: 3401,2947,2889$, 1672, 1593, 1507, 1441, 1389, 1277, 1170, 1114, 1029, 866, $756 \mathrm{~cm}^{-1}$; Found: C, 56.19; $\mathrm{H}, 5.26 ; \mathrm{N}, 8.67 \%$. Calc. for $\mathrm{C}_{15} \mathrm{H}_{16} \mathrm{~N}_{2} \mathrm{O}_{6}(320.30)$; C, 56.25; H, 5.04; N, $8.75 \% . m / z: 320[\mathrm{M}]^{+}(70), 152(34), 151$ $\left[3-\mathrm{MeO}-4-\mathrm{HOC}_{6} \mathrm{H}_{3} \mathrm{CO}\right]^{+}$(100), 123 (35), 108 (18), 77 (9), 55 (23).

\section{Results and Discussion}

The arylglyoxals $\mathbf{2 a - g}$ were prepared from the corresponding acetophenones $1 \mathrm{a}-\mathrm{g}$ by oxidation with $\mathrm{SeO}_{2}$ as outlined in Scheme $2 .^{26-37}$

The arylglyoxals $\mathbf{2 a - g}$ were reacted with 1,3-dimethylbarbituric acid (3) in $\mathrm{H}_{2} \mathrm{O}$ at room temperature to give the corresponding intermediate $\alpha, \beta$-unsaturated triones $\mathbf{4 a - g}$, which were then treated with L-cysteine in presence of phosphotungstic acid under reflux in $\mathrm{H}_{2} \mathrm{O} / \mathrm{EtOH}$ to form 5-[2-aryl2-oxoethyl]-1,3-dimethylpyrimidine-2,4,6-trione derivatives 6a-g as shown in Scheme 3.

The reaction of the intermediate $4 \mathbf{a}$ with L-cysteine (5) in the absence of catalyst gave the corresponding product in only $30 \%$ yield after refluxing for $9 \mathrm{~h}$. As expected, in the absence of L-cysteine, no reaction occurred. Seven examples of the conversion of arylglyoxals $\mathbf{2 a - g}$ into the corresponding 5-[2-aryl-2-oxoethyl]-1,3-dimethylpyrimidine-2,4,6-triones $\mathbf{6 a - g}$ at the optimum reaction conditions are listed in Table 1.

The structures of compounds $\mathbf{6 a - g}$ were elucidated by microanalysis, and their spectral data (FT-IR, ${ }^{1} \mathrm{H}-\mathrm{NMR}$, $\left.{ }^{13} \mathrm{C}-\mathrm{NMR}\right)$. The $\mathrm{X}$-ray crystallographyic analysis of compound $\mathbf{6 f}$, and the mass spectra of compounds $6 \mathbf{a}, \mathbf{6 b}$ and $\mathbf{6 d - g}$ are also reported.

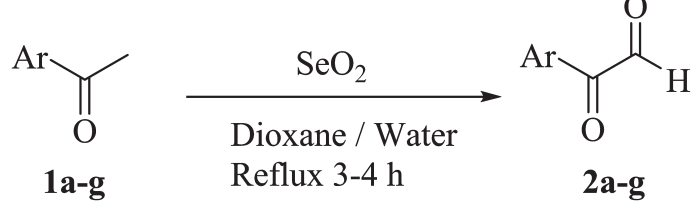
$\mathbf{a} ; \mathrm{Ar}=\mathrm{C}_{6} \mathrm{H}_{5}$
b; $\mathrm{Ar}=4-\mathrm{ClC}_{6} \mathrm{H}_{4}$
c; $\mathrm{Ar}=4-\mathrm{FC}_{6} \mathrm{H}_{4}$
e; $\mathrm{Ar}=4-\mathrm{MeOC}_{6} \mathrm{H}_{4}$
f; $\mathrm{Ar}=3,4-(\mathrm{MeO})_{2} \mathrm{C}_{6} \mathrm{H}_{3}$
g; $\mathrm{Ar}=3-\mathrm{MeO}-4-\mathrm{HOC}_{6} \mathrm{H}_{3}$
d; $\mathrm{Ar}=4-\mathrm{MeC}_{6} \mathrm{H}_{4}$ 


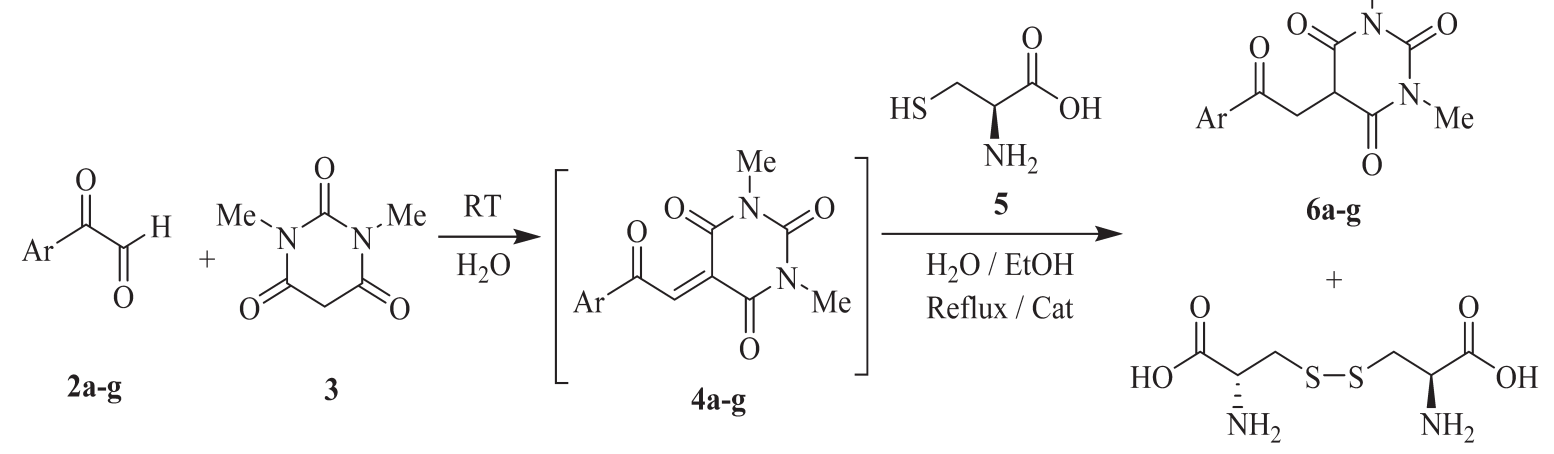
a; $\mathrm{Ar}=\mathrm{C}_{6} \mathrm{H}_{5}$
b; $\mathrm{Ar}=4-\mathrm{ClC}_{6} \mathrm{H}_{4}$
c; $\mathrm{Ar}=4-\mathrm{FC}_{6} \mathrm{H}_{4}$
d; $\mathrm{Ar}=4-\mathrm{MeC}_{6} \mathrm{H}_{4}$
e; $\mathrm{Ar}=4-\mathrm{MeOC}_{6} \mathrm{H}_{4}$
f; $\mathrm{Ar}=3,4-(\mathrm{MeO})_{2} \mathrm{C}_{6} \mathrm{H}_{3}$
g; $\mathrm{Ar}=3-\mathrm{MeO}-4-\mathrm{HOC}_{6} \mathrm{H}_{3}$

Scheme 3

Synthesis of 5-[2-aryl-2-oxo-ethyl]-1,3-dimethylpyrimidine-2,4,6-trione derivatives.

Table 1 The yields, reaction times and melting points of compounds 6a-g.

\begin{tabular}{|c|c|c|c|c|c|}
\hline Entry & Arylglyoxals & Products & Reaction time/min & Yield/\% & M.p. $/{ }^{\circ} \mathrm{C}$ \\
\hline 1 & & & 115 & 71 & 190 [lit., ${ }^{24} 190-191^{\circ} \mathrm{C}$ ] \\
\hline 2 & & & 87 & 75 & 181 \\
\hline 3 & & & 90 & 69 & 162 [lit., $\left.{ }^{24} 162-163^{\circ} \mathrm{C}\right]$ \\
\hline 4 & & & 95 & 76 & 193 \\
\hline 5 & & & 75 & 69 & 191 \\
\hline 6 & & & 70 & 77 & 177 \\
\hline 7 & & & 65 & 72 & 175 \\
\hline
\end{tabular}


The ${ }^{1} \mathrm{H}$ NMR spectra of all compounds $6 \mathbf{a}-\mathrm{g}$ showed a characteristic doublet at around $\delta 3.98-4.07 \mathrm{ppm}$, ascribed to the methylene groups, a triplet at around $\delta 3.56-3.61 \mathrm{ppm}$ due to the $\mathrm{CH}$ group and a singlet at around $\delta 3.35-3.37 \mathrm{ppm}$ due to the methyl groups of the 1,3-dimethylbarbituric acid moiety. In ${ }^{13} \mathrm{C}$ NMR spectra, signals around $195 \mathrm{ppm}$ were ascribed to the ketone carbonyl, and the two singlets around 168 and 153 ppm to the amide carbonyl groups. In the FT-IR spectra, the characteristic absorption bonds at $1664-1673 \mathrm{~cm}^{-1}$ could be assigned to the vibrations of the above-mentioned carbonyl groups. The mass spectra of all compounds showed aroyl cations as main fragments with $100 \%$ abundance.

The proposed mechanism for reduction of 5-arylidene-1,3dimethylbarbituric acid $\mathbf{4 a - g}$ by L-cysteine (5) in presence of phosphotungstic acid is shown in Scheme 4. The proton absorption by $\alpha, \beta$-unsaturated triketones $4 \mathbf{a}-\mathbf{g}$ forms the carbocations $7 \mathrm{a}-\mathrm{g}$ with electron-deficient carbon near to aroyl group, which was changed to carbanions $\mathbf{8 a}-\mathbf{g}$ by transfer of two electrons from cysteine and finally formed the desired trione $\mathbf{6 a - g}$ by absorption of the second proton. It seems that electron-donating substituents on arylglyoxals stabilizes the carbocations $7 \mathrm{a}-\mathrm{g}$ formed in the first step, as the reaction with 4-nitro substituent failed to form the corresponding reduced triketone, due to destabilization of carbocations formation in the first step by electron-withdrawing effect of nitro substituent.

The metal ions in phosphotungstic acid catalyzes the oxidation of L-cysteine to L-cystine.<smiles>NC(CSSCC(N)C(=O)O)C(=O)O</smiles>

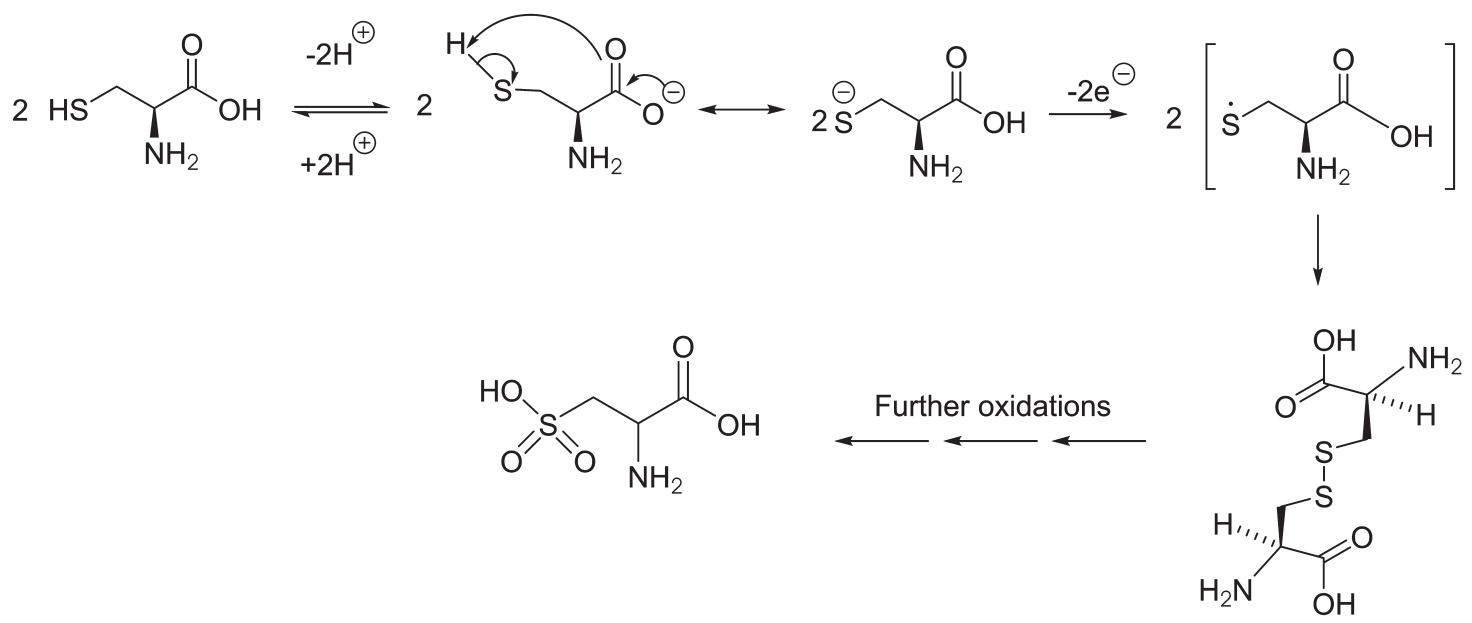

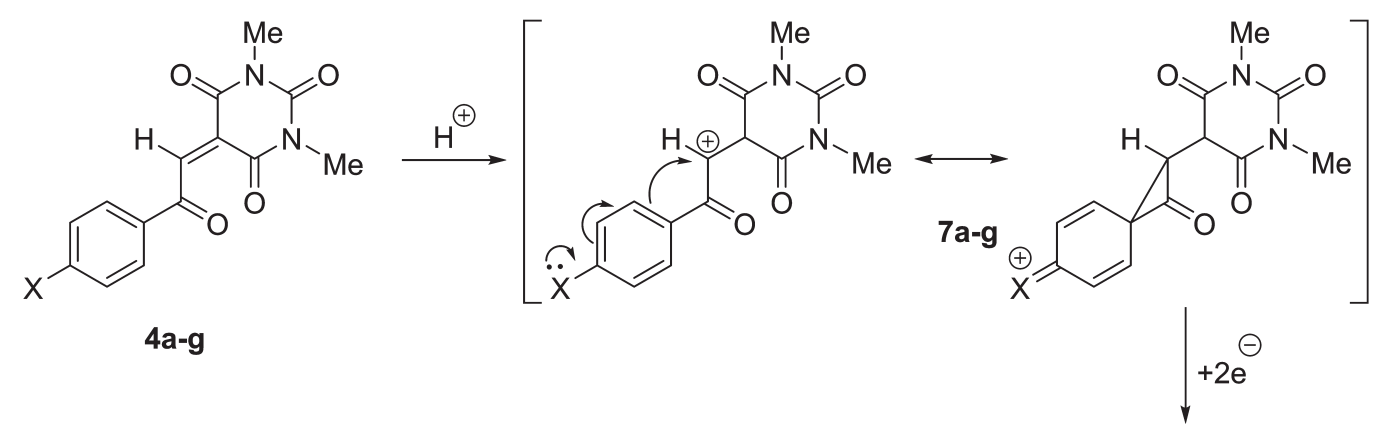<smiles>[X]c1ccc(C(=O)C2C(=O)C(CCCC)C(=O)N([Y6])C2=O)cc1</smiles>

6a-g

$\mathrm{X}=\mathrm{H}, \mathrm{Cl}, \mathrm{F}, \mathrm{Me}, \mathrm{OMe}, \mathrm{OH}$

Scheme 4

The proposed mechanism for reaction. 


\section{Conclusions}

We have synthesized some barbituric acid derivatives via the one-pot, three-component reaction of arylglyoxals, 1,3-dimethylbarbituric acid and L-cysteine in $\mathrm{H}_{2} \mathrm{O} / \mathrm{EtOH}$. The resulting 5-[2-aryl-2-oxoethyl]-1,3-dimethylpyrimidine-2,4,6-triones synthesized would appear to be suitable synthetic intermediates for a series of new planar polycyclic heterocycles such as pyrimido $[4,5-c]$ pyrazines ${ }^{38}$ and pyrazolo[2,3- $\left.d\right]$ pyrimidines, ${ }^{39}$ with possible pharmaceutical applications.

\section{Supplementary Data}

Other supplementary data $\left({ }^{1} \mathrm{H}-\mathrm{NMR},{ }^{13} \mathrm{C}-\mathrm{NMR}, \mathrm{IR}\right.$ and mass spectra) associated with this article are available in the online supplement.

\section{Acknowledgements}

The authors are grateful to Urmia University for financial support and also thank Professor R.H. Prager (Flinders University, Australia) for proofreading of this article.

\section{References}

1 B.H. Rotstein, S.A. Zaretsky, V. Rai and A.K. Yudia, Small heterocycles in multicomponent reactions, Chem. Rev., 2014, 114, 8323-8359.

2 O.V. Ershov, M.Y. Ievler, V.A. Tafeenko and O.E. Naskin, Glycine catalyzed diastereoselective domino-synthesis of 6-imino-2,7-dioxabicyclo[3.2.1] octane-4,4,5-tricarbonitriles in water. Green. Chem., 2015, 17, 4234-4238.

3 S.R. Vidadala and H. Waldmann, Palladium and copper catalyzed Sonogashira decarboxylative coupling of aryl iodides and alkynyl carboxylic acids, Tetrahedron Lett., 2015, 56, 3358-3362.

4 C.L. Peck, J.A. Calderone and W.L. Santos, Copper(II)-catalyzed $\beta$-borylation of acetylenic esters in water, Synthesis., 2015, 47, 2242-2248.

5 Z. Fu, K. Qian, S. Li and T. Shen, $\mathrm{MgCl}_{2}$ catalyzed one-pot synthesis of 2-hydroxy-3-((5-methyl-3-oxo-2-phenyl-2,3-dihydro-1H-pyrazol-4yl)(phenyl)methyl)naphthalene-1,4-dione derivatives in EG, Tetrahedron Lett., 2016, 57, 1104-1108.

6 S.B. Azimi and J. Azizian, Reaction of benzyl alcohols, isatoic anhydride, and primary amines mediated by $\mathrm{I}_{2} / \mathrm{K}_{2} \mathrm{CO}_{3}$ in water: a new and green approach for the synthesis of 2,3-dihydroquinazolin-4(1H)ones, Tetrahedon Lett., 2016, 57, 181-184.

7 A. Habibi and Z. Tarameshloo, A new and convenient method for synthesis of barbituric acid derivatives, J. Iran. Chem. Soc., 2011, 8, 287-291.

8 R. Rastaldo, C. Penna and P. Pagliaro, Comparison between the effects of pentobarbital or ketamine/nitrous oxide anesthesia on metabolic and endothelial components of coronary reactive hyperemia, Life Sci., 2001, 69, 729-738.

9 B.S. Jursic and D.E. Stevens, Transition metal free reductive dimerization of nitrogen containing barbituric acid benzylidenes, J. Heterocycl. Chem., 2003, 40, 701-706.

10 S. Kotha, A. Dep and R. Kumar, Design and synthesis of spiroannulated barbituric acid derivatives and its analogs by ring-closing metathesis reaction as key steps, Bioorg. Med. Chem. Lett., 2005, 15, 1039-1043.

11 M.E. Wolff, Burger's Medicinal Chemistry and Drug Discovery, Wiley, New York, USA, 1997.

12 M. Holtkamp and H. Meierkord, Anticonvulsant, antiepileptogenic and antiestrogenic pharmacy strategies, Cell. Mol. Life Sci., 2007, 64 2023-2041

13 V. Malhotra, S.R. Pathak, R. Nath, D. Mukherjee and K. Shanker, Substituted imidazole derivatives as novel cardiovascular agents, Bioorg. Med. Chem. Lett., 2011, 21, 936-939.

14 Y. Özkay, I. Ipikdað, Z. Ýncesu and G. Akalin, Synthesis of 2-substituted- $N$-[4-(1-methyl-4,5-diphenyl-1H-imidazole-2-yl)phenyl]aceta mide derivatives and evaluation of their anticancer activity, Eur. J. Med. Chem., 2010, 45, 3320-3328.

15 H.M. Refaat, Synthesis and anticancer activity of some novel 2-substituted benzimidazole derivatives, Eur. J. Med. Chem., 2010, 45, 2949-2456.

16 C. Congiu, M.T. Cocco and V. Onnis, Design, synthesis, and in vitro antitumor activity of new 1,4-diarylimidazole-2-ones and their 2-thione analogs, Bioorg. Med. Chem. Lett., 2008, 18, 989-993.

17 K.U. Ingold, Inhibition of the autoxidation of organic substances in the liquid phase, Chem. Rev., 1961, 61, 563-566.

18 P.C. Jocelyn, The occurrence, chemical properties, metabolism and biological function of thiols and disulphides, Biochemistry of the $\mathrm{SH}$ Group, Academic Press, New York, USA, 1972.

19 K. Schafer, M. Bonifaeii, D. Bahnemann and K.-D. Asmus, Addition of oxygen to organic sulfur radicals, J. Phys. Chem., 1978, 82, 2777-2780.

20 B.C. Gilbert, H.A.H. Laue, R.O.C. Norman and R.C. Sealy, Electron spin resonance studies. Part XLVI. Oxidation of thiols and disulphides in aqueous solution: formation of RS', $\mathrm{RSO}^{\circ}, \mathrm{RSO}_{2}{ }^{\circ}, \mathrm{RSSR}-$, and carbon radicals, J. Chem. Soc. Perkin Trans II., 1975, 892-900.

21 S. Sulzer-Moss and A. Alexakis, Chiral amines as organocatalysts for asymmetric conjugate addition to nitro olefins and vinyl sulfones via enamine activation, Chem. Commun., 2007, 30, 3123-3135.

22 N. Krause and A. Hoffmann-Roder, Recent advances in catalytic enantioselective Michael additions, Synthesis, 2001, 2, 171-196.

23 H.J. Al-Najjar, A. Barakat, A.M. Al-Majid, Y.N. Mabkhot, M. Weber, H.A. Ghabbour and H-K. Fun, A green, efficient approach to Michael addition of barbituric acid to nitroalkene in aqueous diethylamine medium, Molecules, 2014, 19, 1150-1162.

24 a) N.N. Kolos, N.V. Chechina, L.L. Zamigailo and E.V. Vashchenko, Simple and efficient synthesis of trisubstituted imidazoles, Chem. Heterocycl. Comp., 2013, 49, 872-881. b) K. Asahi and H. Nishino, Facile endoperoxypropellane synthesis by manganese(III) acetate-mediated aerobic oxidation, Eur. J. Org. Chem., 2008, 14, 2404-2416.

25 K. Tanaka, X. Chen, T. Kimura and F. Yoneda, Oxidation of thiol with 5-arylidene-1,3-dimethylbarbituric acid: application to synthesis of unsymmetrical disulfide, Tetrahedron, 1988, 44, 3241-3249.

26 H.A. Riley and A.R. Gray, Organic Syntheses, Wiley \& Sons, New York, Collect. II., 1943, p. 509.

27 B. Khalili, T. Tondro and M.M. Hashemi, Novel one-pot synthesis of (4 or 5)-aryl-2-aryloyl- $(1 H)$-imidazoles in water and auto-isomerization study using NMR, Tetrahedron, 2009, 65, 6882-6887.

28 J. Khalafy, B. Parsa Habashi, A. Poursattar Marjani and P. Najafi Moghadam, The synthesis of 2-arylquinoxaline derivatives, Curr. Chem. Lett., 2012, 1, 139-146.

29 J. Khalafy, M. Rimaz, S. Farajzadeh and M. Ezzati, A simple threecomponent synthesis of 3-amino-5-arylpyridazine-4-carbonitriles, S. Afr. J. Chem., 2013, 66, 179-182.

30 J. Khalafy, M. Rimaz, H. Rabiei and L. Panahi, An efficient one-pot protocol for regioselective synthesis of 3-aryl-6,8-dialkyl-7-thioxo7,8-dihydropyrimido[4,5-c]pyridazine-5(6H)-ones, J. Sulf. Chem., 2013, 34, 395-406.

31 B. Eftekhari-Sis, M. Zirak and A. Akbari, Arylglyoxals in synthesis of heterocyclic compounds, Chem. Rev., 2013, 113, 2958-3043.

32 J. Khalafy, A. Poursattar Marjani and M. Haghipour, Regioselective synthesis of 3-arylpyrido[2,3-b]pyrazines by reaction of arylglyoxals with 2,3-diaminopyridine, Curr. Chem. Lett., 2013, 2, 21-26.

33 J. Khalafy, M. Ezzati, M. Rimaz, A. Poursattar Marjani and H. Yaghoobnejad Asl, An efficient and facile regioselective synthesis of new substituted (E)-1-(3-aryl-7,8-dihydrocinnoline-5(6H)-ylidene) hydrazines and $(1 E, 2 E)$-1,2-bis(3-aryl-7,8-dihydrocinnoline5(6H)-ylidene)hydrazines, J. Iran. Chem. Soc., 2014, 11, 1067-1074.

34 J. Khalafy, N. Etivand, S. Dilmaghani, M. Ezzati and A. Poursattar Marjani, A convenient and mild synthesis of new 2-aryl-3-hydroxy6,7-dihydro- $1 H$-indol-4(5H)-ones via a one-pot, three-component reaction in water, Tetrahedron Lett., 2014, 55, 3781-3783.

35 A. Poursattar Marjani, J. Khalafy and S. Mahmoodi, A simple one-pot synthesis of new 9-aroyl-3,4,6,7,9,10-hexahydro-1,8(2H,5H)-acridinediones, ARKIVOC., 2016, iii, 262-270.

36 A. Poursattar Marjani, J. Khalafy, M. Chitan and S. Mahmoodi, Microwave-assisted synthesis of acridine- $1,8(2 H, 5 H)$-diones via a one-pot, three component reaction, Iran. J. Chem. Chem. Eng., 2017, 36, 1-6.

37 A. Poursattar Marjani, J. Khalafy and A. Haghi, An efficient route for the synthesis of 11 -aroyldiindeno[1,2-b:2',1'-e]pyridine-10,12-diones, J. Heterocycl. Chem., 2017, in press. DOI 10.1002/jhet.2949.

38 M. Rimaz, P. Pourhossein and B. Khalili, Regiospecific one-pot, combinatorial synthesis of new substituted pyrimido[4,5-c]pyridazines as potential monoamine oxidase inhibitors, Turk. J. Chem., 2015, 39, 244-254

39 S.C. Azimi and K. Rad-Moghadam, A clean and highly efficient synthesis of oxindole substituted pyrrolo[2,3- $d$ ]pyrimidines under ultrasound irradiation, Iran. Chem. Commun., 2017, 5, 156-166. 